http://jmscr.igmpublication.org/home/ ISSN (e)-2347-176x ISSN (p) 2455-0450 crossref DOI: https://dx.doi.org/10.18535/jmscr/v8i6.85

\title{
Umbilical Cord Hernia a Rare Ventral Wall Defect: Case Report
}

\author{
Authors \\ Priyanka Sharma1, Nishant Acharya ${ }^{2 *}$ \\ ${ }^{1}$ Department of OBG, Bhandari Hospital Hamirpur (H.P), India \\ ${ }^{2}$ Department of Paediatrics, Dr. RKGMC Hamirpur (H.P), India \\ *Corresponding Author \\ Nishant Acharya
}

\begin{abstract}
Umbilicus is a site of numerous embryopathies involving vessels, urachus, midgut herniation, anterior abdominal wall defects and congenital cysts. Abdominal wall defects can range from lethal limb-body wall syndrome to benign umbilical cord hernias (UCH), which are often misdiagnosed as omphalocele minor causing unwarranted anxiety. A meticulous evaluation of prenatal ultrasounds and palpation of the cord before clamping after the delivery are the mainstay for early and accurate diagnosis. We are illustrating a case of umbilical cord hernia (UCH) in which though the ultrasonography (USG) was unable to establish the diagnosis antinatally but the thorough clinical examination not only diagnosed but also prevented the unwarranted complication.
\end{abstract}

Keywords: Umbilical cord hernia, Ventral wall defect, Reducible swelling of cord, Umbilical embryopathies.

\section{Introduction}

Umbilicus is a site of numerous embryopathies involving vessels, urachus, midgut herniation, anterior abdominal wall defects and congenital cysts. Abdominal wall defects represent a wide spectrum of congenital anomalies. These can range from lethal limb-body wall syndrome to benign umbilical cord hernias $(\mathrm{UCH})$. They differ widely in their underlying pathogenesis, genetics, and associated disorders consequently, their management techniques and outcomes are quite different.

$\mathrm{UCH}$ is an entity that has been poorly understood and often misdiagnosed as omphalocele minor ${ }^{[1]}$. It is thought to arise from persistence of physiological herniation of the mid-gut beyond 10-12 weeks gestation $^{[2]}$. Incidence is estimated to be about 1 in $5000^{[3]}$. UCH are thought to be benign with favourable outcomes, and its isolated presentation has not been associated with other chromosomal anomalies $^{[4]}$. Owing to the lack of awareness of this entity, it is often misdiagnosed and under-reported, with limited data in the literature. We are illustrating a case of umbilical cord hernia in which though the ultrasonography (USG) was unable to establish the diagnosis antinatally but the thorough clinical examination not only diagnosed but also prevented the unwarranted complication. 
Table 1 Contrasting features of various ventral wall defects

\begin{tabular}{|c|c|c|c|}
\hline $\begin{array}{l}\text { Characteristi } \\
\mathrm{c}\end{array}$ & $\begin{array}{l}\text { Umbilical } \\
\text { cord hernia }\end{array}$ & Omphalocele & Gastroschisis \\
\hline Sac & Intact skin & $\begin{array}{l}\text { Peritoneum, } \\
\text { Wharton jelly, } \\
\text { amnion }\end{array}$ & Absent \\
\hline Aetiology & $\begin{array}{l}\text { Persistence of } \\
\text { physiological } \\
\text { mid-gut } \\
\text { herniation } \\
\text { beyond } \\
10-12 \text { weeks } \\
\text { gestation }{ }^{[2]}\end{array}$ & $\begin{array}{l}\text { Large } \\
\text { umbilical } \\
\text { defect resulting } \\
\text { from a failure } \\
\text { of closure of } \\
\text { the ventral } \\
\text { abdominal wall } \\
{[4]}\end{array}$ & $\begin{array}{l}\text { Several } \\
\text { hypotheses; } \\
\text { disruption of } \\
\text { the right } \\
\text { umbilical vein } \\
{[10]}\end{array}$ \\
\hline $\begin{array}{l}\text { Stage of } \\
\text { acquisition }\end{array}$ & $\begin{array}{l}\text { 12-14 weeks } \\
\text { [2] }\end{array}$ & $3-5$ weeks ${ }^{[2]}$ & 5-6 weeks ${ }^{[2]}$ \\
\hline Incidence & $\begin{array}{l}1 \text { in } 5000^{[9]} \\
\text { Under- } \\
\text { reported }\end{array}$ & 1 in 4000 [9] & 1 in $2000^{[9]}$ \\
\hline $\begin{array}{l}\begin{array}{l}\text { Location of } \\
\text { defect }\end{array} \\
\end{array}$ & Umbilicus & Umbilicus & $\begin{array}{ll}\begin{array}{l}\text { Right } \\
\text { umbilicus }\end{array} & \text { of } \\
\end{array}$ \\
\hline $\begin{array}{l}\text { Associated } \\
\text { anomalies }\end{array}$ & $\begin{array}{l}\text { Rare case } \\
\text { reports of } \\
\text { associated } \\
\text { bowel } \\
\text { anomalies and } \\
\text { umbilical } \\
\text { cord cysts [1], } \\
{[4],[7]}\end{array}$ & $\begin{array}{l}50-70 \% \text { of } \\
\text { them have } \\
\text { other major } \\
\text { anomalies }^{[11]}\end{array}$ & $\begin{array}{l}8-10 \% \\
\text { association } \\
\text { with other } \\
\text { major } \\
\text { anomalies and } \\
1-3 \% \\
\text { association } \\
\text { with cardiac } \\
\text { anomalies }{ }^{[10]}\end{array}$ \\
\hline $\begin{array}{l}\text { Prenatal } \\
\text { ultrasound }\end{array}$ & $\begin{array}{l}\text { Small bowel } \\
\text { extending into } \\
\text { the } \\
\text { base of the } \\
\text { normally } \\
\text { inserted } \\
\text { umbilical } \\
\text { cord }^{[4]}\end{array}$ & $\begin{array}{l}\text { Fetal midline } \\
\text { abdominal } \\
\text { mass } \\
\text { with the } \\
\text { umbilical cord } \\
\text { attaching } \\
\text { at the apex of } \\
\text { the mass }{ }^{[11]}\end{array}$ & $\begin{array}{l}\text { Exteriorised } \\
\text { bowel floating } \\
\text { freely in the } \\
\text { amniotic } \\
\text { cavity adjacent } \\
\text { to a normally } \\
\text { inserted } \\
\text { umbilical cord } \\
{[12]}\end{array}$ \\
\hline Prognosis & Excellent & $\begin{array}{ll}\text { Depends } & \text { on } \\
\text { associated } & \\
\text { anomalies } & \end{array}$ & $\begin{array}{l}\text { Good } \\
\text { prognosis; } \\
25 \% \text { cases } \\
\text { associated } \\
\text { with bowel } \\
\text { complication } \\
{[10]}\end{array}$ \\
\hline
\end{tabular}

\section{Case Report}

A small for gestational age female neonate was born through normal vaginal delivery in the labour room. Baby was born vigorous and while providing routine care to the neonate a swelling was noticed in the umbilical cord and the contents of the cord were reducible. The skin of the umbilical ring was intact. Umbilical cord was clamped away from the swelling. The antinatal USG was normal and not suggestive of any anterior abdominal wall defect. Keeping the clinical possibility of umbilical cord hernia an USG was performed which illustrated bowel loops as a content within the umbilical cord. On second day of life the swelling became irreducible while urinary and bowel habits were normal. X-ray abdomen depicted dilated gut loops. An emergency reduction and repair of the defect was done with intraoperative finding of caecum and appendix as the contents of the defect. All investigations to find any other associated congenital abnormality were unremarkable.

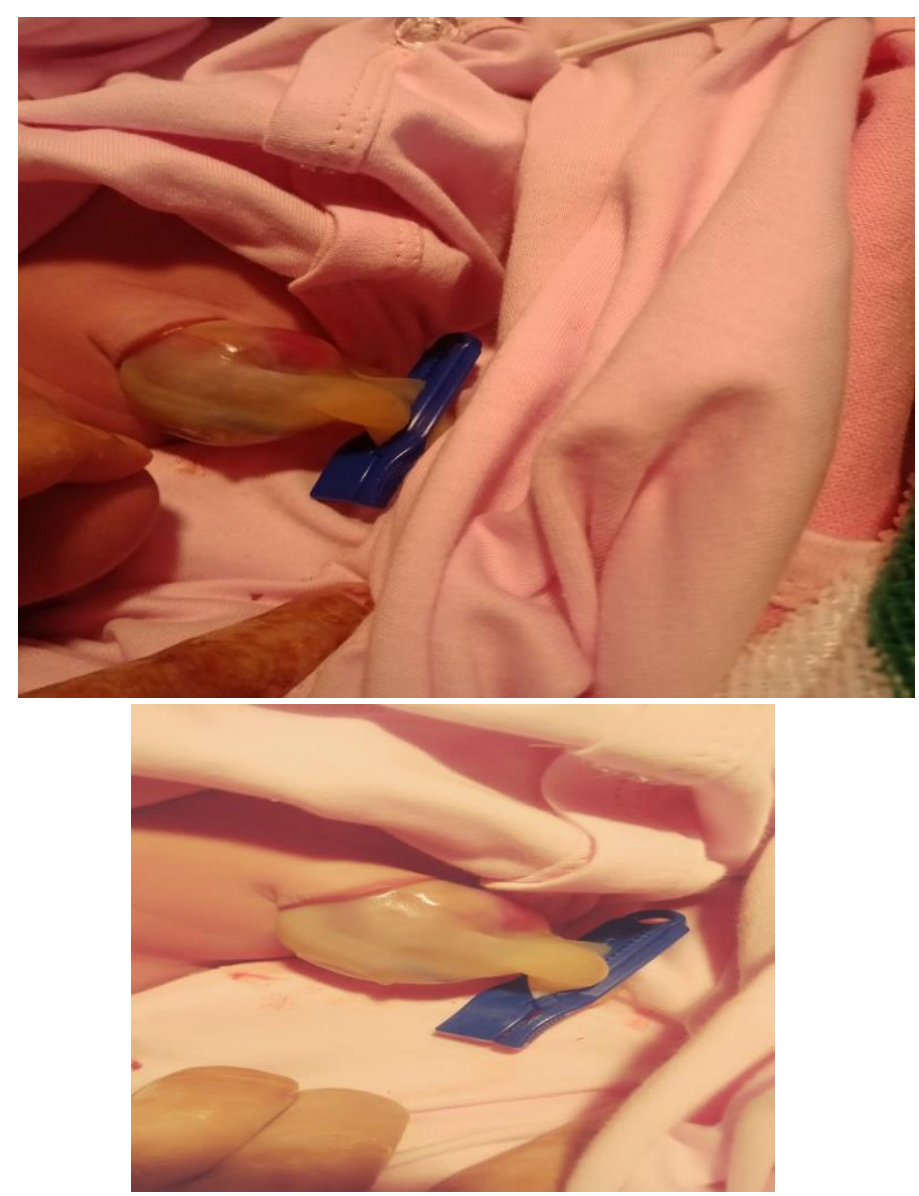

Fig. 1 (a), (b) Umbilical cord hernia

\section{Discussion}

Umbilicus is a common site of wide spectrum of developmental anomalies like ventral wall anomalies ranging from limb-body wall syndrome to benign umbilical cord hernias (UCH). During early fetal life there is physiological herniation of a greater portion of the intestines into extracelomic cavity which later develops as the proximal part of the umbilical cord. At about 10-12 wks gestation, intestines withdraw into the abdominal cavity, the umbilical ring mostly closes and the extracelomic cavity disappears leaving behind Wharton's jelly 
and umbilical vessels in the cord. In rare instances, the umbilical ring does not close and variable portions of the intestines remain in the extracelomic cavity which present at birth as congenital hernia into the umbilical cord ${ }^{[3]}$. Umbilical cord hernia was first described in the literature by Hempel-jorgensen in 1929, he reported two cases of this entity in a family and had coined the term 'familial congenital umbilical hernia ${ }^{[5]}$. Ever since only few case reports have been published clearly describing this entity $^{[1],[2],[3],[6]}$. Achiron et al has demonstrated that UCH occurs at early embryological stage and can be detectable at early 2 nd trimester on antenatal USG ${ }^{[2]}$, but in our case the anomaly was missed twice antenatally during second and third trimester USG. A meticulous antenatal USG is recommended in the early $2^{\text {nd }}$ trimester to prevent misdiagnosis and unwarranted anxiety. The case reported by Raju R, et al which was antinatally undiagnosed resulted in an enterotomy during cord clamping. Prenatal diagnoses as well as thorough clinical examination are important to prevent inadvertent injury to the bowel during cord clamping at the time of delivery [7].

Klein et al described umbilical cord hernias as being associated with intestinal malrotation ${ }^{[4]}$. Pal et al described them as being associated with persistent vitello-intestinal duct, cloacal anomalies and intestinal atresi ${ }^{[1]}$. Haas et al, in their case series of eight patients, recommended that $\mathrm{UCH}$ associated with bowel complications like with umbilical cord cysts, intestinal dilation and ascites, and hyperechoic short bowel. He recommended the need of close monitoring and early induction of labour should be done between 34 and 36 weeks' gestation. Postnatally, umbilical cord hernias are usually managed with primary surgical closure that is reduction of the content and closure of primary $\operatorname{defect}^{[2],[4]}$.

\section{Conclusions}

A meticulous evaluation of prenatal ultrasounds and palpation of the cord before clamping after the delivery are very important to prevent unwarranted anxiety from misdiagnosis and inadvertent bowel injury while clamping the cord at delivery. Increased awareness and knowledge of umbilical cord hernias among health professionals is desired for its accurate diagnosis and appropriate management.

\section{References}

1. Pal K, Ashri H, Wabari A. Congenital hernia of the cord. Indian J Pediatr 2009; 76:31921.

2. Achiron R, Soriano D, Lipitz S, et al. Fetal midgut herniation into the umbilical cord: improved definition of ventral abdominal anomaly with the use of transvaginal sonography. Ultrasound Obstet Gynecol 1995; 6:256-60.

3. Burns CW, Ogryzlo MA. Congenital hernia into the umbilical cord: two cases associate with persistent cloaca. Can Med Assoc J 1938; 39:438-41.

4. Klein M, Kosloske AM, Hertzler JH. Congenital defects of the abdominal wall: a review of the experience in New Mexico. JAMA 1981; 245:1643-6.

5. Hempel-Jorgensen P. Familial congenital umbilical hernia. Ugesk f Laeger 1929; 91:273-274.

6. Tow. Diseases of the Newborn NewYork; Oxford Medical Publication, 1937, 224-226.

7. Haas J, Achiron R, Barzilay E, et al. Umbilical cord hernias: prenatal diagnosis and natural history. J Ultrasound Med 2011; 30:1629-32.

8. Raju R, et al. Congenital hernia of cord: an often misdiagnosed entity. BMJ 2015. doi:10.1136/bcr-2015-209642.

9. Glasser J. Pediatric omphalocele and gastroschisis. 2014. http://emedicine. medscape.com/article/975583-overview (accessed 31 May 2020).

10. Stephensen C, Lockwood C, MacKenzie A. Gastroschisis. 2015. http://www.uptodate.com/contents/gastrosch isis?source=search_result\&search=gastrosch 
isis\&selectedTitle=1 33 (accessed 31 May 2020).

11. Khan

Ali

N. Omphalocele.

http://emedicine.medscape.com/article/4041

82-overview\#a22 (accessed 31 May 2020).

12. Khan Ali N. Gastroschisis. http://emedicine.medscape.com/article/4038

00-overview\#a22 (accessed 31May 2020). 